\title{
Fine needle aspiration biopsy of the thyroid gland: a study of 304 cases
}

\author{
KENNETH C SUEN, NOEL F QUENVILLE* \\ From the Department of Pathology, and the *Division of Anatomical Pathology, Vancouver General \\ Hospital, University of British Columbia, Vancouver BC, Canada
}

SUMMARY We discuss the interpretation of thyroid aspiration cytology in the light of our experience and review the circumstances in which false positives and false negatives may occur. The technique is reliable but by no means infallible and it should not be regarded as a final diagnostic work-up. Its value lies in selecting patients with thyroid nodules for surgery. In the present series of 304 patients, 79 underwent operation and 37 malignancies were found. The incidence of malignancy among the surgically excised nodules was $47 \%$, in contrast to $14 \%$ in the past. We estimated that 268 operations would be required to salvage the same number of malignancies without the use of fine needle aspiration biopsy.

Whether one should excise a "cold" thyroid nodule or manage it conservatively is a question that continues to provoke controversy. ${ }^{1-3}$ The main reason for such a problem to exist is that thyroid nodules are common while the incidence of thyroid cancer is low. Based on necropsy data, Sokal estimated that fewer than $1 \%$ of unselected nodular goitres were malignant. ${ }^{4}$ On the other hand, in most series of surgically excised thyroid nodules about $10 \%$ to $20 \%$ proved to be malignant on histological examination..$^{5-7}$ The higher incidence of malignancy among the surgically treated patients reflects preoperative efforts in patient selection and does not give a true picture of the natural course of all the thyroid nodules in the general population. Nevertheless, with a five to one chance that the nodule removed is benign, there is obviously a need for more precision in the preoperative discrimination between malignant and benign thyroid nodules. We have been interested in evaluating the fine needle aspiration biopsy (FNAB) in fulfilling this need. This paper reviews our experience with FNAB performed at a large municipal hospital during the four-year period, 1978-1981. Reliable follow-up information and sufficient experience have now accumulated to answer many of the questions regarding the advantages and pitfalls of the aspiration technique. The literature on this subject is also reviewed.

Accepted for publication 20 April 1983

\section{Material and methods}

Fine needle aspiration biopsy can be safely per formed on an outpatient basis. The patient lies com fortably in a supine position and the neck iș extended with a pillow placed under the shoulders and neck. The skin overlying the lesion is cleaned with an antiseptic. No local anaesthesia is required. The lesion is punctured with a 23 gauge needle connected to a $10 \mathrm{ml}$ air-tight plastic syringe. When the needle has entered the nodule, the plunger is then retracted to create a vacuum in the syringe. The needle is moved back and forth several times within the lesion as material is aspirated into the needle by the negative pressure. Just prior to the withdrawal of the needle from the lesion, the plunger is released to eliminate the vacuum, thereby avoiding aspiration of the sample into the syringe barrel. To expel the aspirated material onto the glass slides, the needle containing the sample is first detached from the syringe and the plunger is withdrawn to allow air into the syringe. The needle is re-attached and the needle content is ejected on the slides by pushing down the plunger. Several smears are made and promptly fixed in $95 \%$ ethyl alcohol for haematoxylin and eosin or Papanicolaou staining. The needle and syringe are rinsed with physiological saline and the contents are used for membrane filter preparation. With experience, one can also reliably judge the adequacy of a sample by naked-eye examination of the prepared smears. If the sample is considered 
inadequate, aspiration is repeated immediately.

Other investigators, particularly those with training in haematology, have preferred air-dried smears stained by a Romanovsky method. We have chosen the haematoxylin and eosin technique partly because it is a stain more familiar to tissue pathologists and it facilitates morphological correlation between cells seen in the smears and in the tissue sections. Both the haematoxylin and eosin and the Papanicolaou stains performed on alcohol-fixed smears provide sharp nuclear detail which is less evident on Romanovsky-stained smears. However, the latter stain delineates better metachromatic substances such as connective tissue stroma and colloid material. The choice of staining procedures depends on the pathologist's training background and it will not affect the results so long as he is familiar with the stain and is using the same technique consistently.

During the four-year period from 1978 to 1981, at the Vancouver General Hospital, there was a total of 331 fine needle aspiration biopsies of the thyroid, of which 27 were subsequently excluded from this study for the following reasons: inadequate material for interpretation (15 cases), no follow-up data available (11 cases) and metastatic carcinoma from other site (1 case). The remaining 304 cases constituted the basis for this study. All the patients had radioiodine scintiscanning and $96 \%$ had ultrasonography. Solitary "cold" nodules and multinodular goitres with the presence of one dominant "cold" nodule accounted for 235 cases or $78 \%$ of the total. Ultrasound further divided the "cold" nodules into solid (126 cases), cystic (64 cases) and mixed (45 cases). At the time of the biopsy the patient was examined by the clinician and the pathologist, and all clinical and laboratory data were reviewed. The close collaboration between the pathologist and the clinicians has proved to be extremely valuable, not only for the technical preparation of the smears but also for the correlation of the cytological findings with the clinical and laboratory findings.

\section{CYTOLOGICAL INTERPRETATION}

\section{Poorly differentiated carcinomas (Fig. 1)}

Cytological diagnosis of this group of tumours does not pose a problem. The smears contain abundant neoplastic cells which are loosely cohesive. The usual cellular criteria of malignancy are present, such as anisokaryosis, nuclear hyperchromatism, irregular chromatin clumping and frequently prominent nucleoli.

\section{Papillary carcinoma}

The aspirated material contains mostly intact tissue

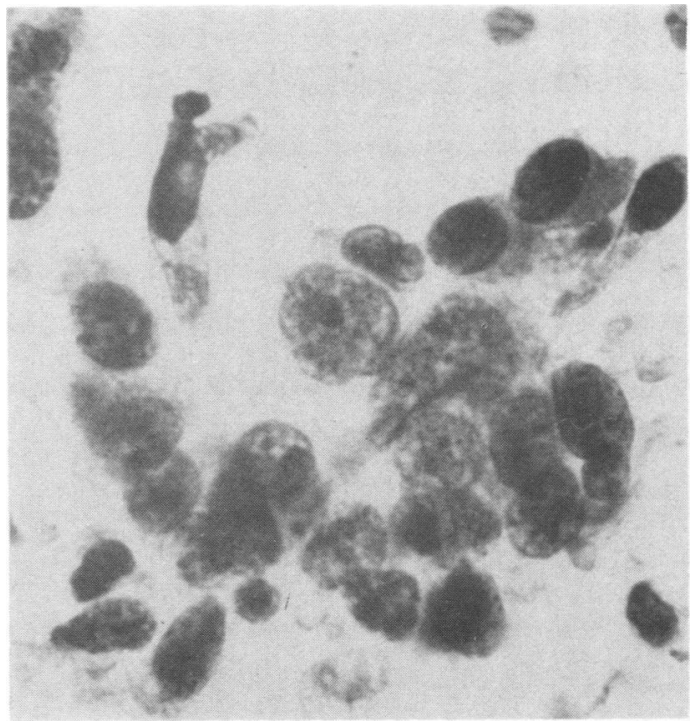

Fig. 1 Poorly differentiated thyroid carcinoma. Note loose cellular cohesion, marked anisokaryosis, and hyperchromatism with coarse clumping and clearing of chromatin. Haematoxylin and eosin $\times 520$.

fragments rather than free cells. In a typical cellular sample, there are three types of tissue fragments: papillary, monolayered and multilayered. The papillary tissue fragment is diagnostic for this tumour type and it exhibits a stereoscopic configuration best appreciated by moving the plane of focus of the microscope up and down, a smooth well-defined peripheral outline and a complex ramifying pattern reflecting papillary growth (Fig. 2). The constituent cells are crowded and may show nuclear overlapping or moulding, but size variation is usually minimal. The nuclei are characteristically hypochromatic and vesicular or glassy, with a small nucleolus. In some aspirates, only smaller or single papillary fronds are present (Fig. 3). A monolayered tissue fragment displays tumour cells in one plane of focus. The lack of a three-dimensional configuration with flattening of cells in smears probably helps to exaggerate the size of the tumour cells, which generally appear to be larger than those in the papillary fragments; nuclear pleomorphism is also more evident (Fig. 4a). Sometimes carcinoma cells appear squamoid, without signs of keratinisation. The squamoid changes are most often seen in monolayered tissue fragments (Fig. 4b). A multilayered tissue fragment consists of markedly superimposed tumour cells with apparent disorganisation and the fragment contour exhibits irregularity (Fig. 5a). Both monolayered and multilayered fragments do not permit accurate typing of the cancer unless an additional finding of "ground 


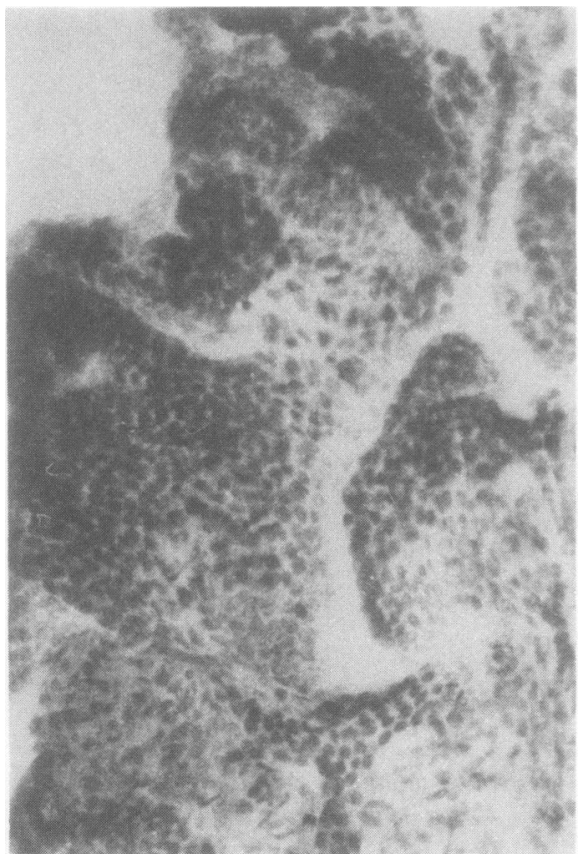

Fig. 2 A large papillary tissue fragment composed of numerous papillary fronds, giving rise to a complex ramifying pattern. Haematoxylin and eosin $\times 125$. glass" nuclei or psammoma bodies is present. The finding of multilayered tissue fragments is common in aspirates of any cellular neoplasms and they are not necessarily derived from a papillary carcinoma. In about $50 \%$ of our cases, the tumour cells exhibit intranuclear inclusions of the cytoplasm, so-called pseudonucleoli (Fig. 4a). Although commonly associated with thyroid papillary carcinoma, these cytoplasmic invaginations have been observed in other lesions including adenocarcinomas and melanoma ${ }^{89}$ Twenty per cent of our aspirates contain psammoma bodies. These are basophilic, laminated spherules measuring $30-100 \mu \mathrm{m}$ in diameter (Fig. 5b), and must not be confused with dystrophic calcifications which can be seen in involutional goitres and occur as irregular, basophilic speckles lacking distinct laminations. In $10 \%$ of our cases, a great number of lymphocytes are admixed with the tumour cells. An erroneous diagnosis of chronic lymphocytic thyroiditis may be made by the unwary because the numerous lymphocytes can obscure the presence of tumour cells.

\section{Follicular carcinoma}

The aspirates are hypercellular and contain tumour cells that are dispersed, loosely arranged in follicular formations or grouped in tissue fragments withing which a follicular pattern may sometimes be seen? Cellular atypia varies from case to case, depending

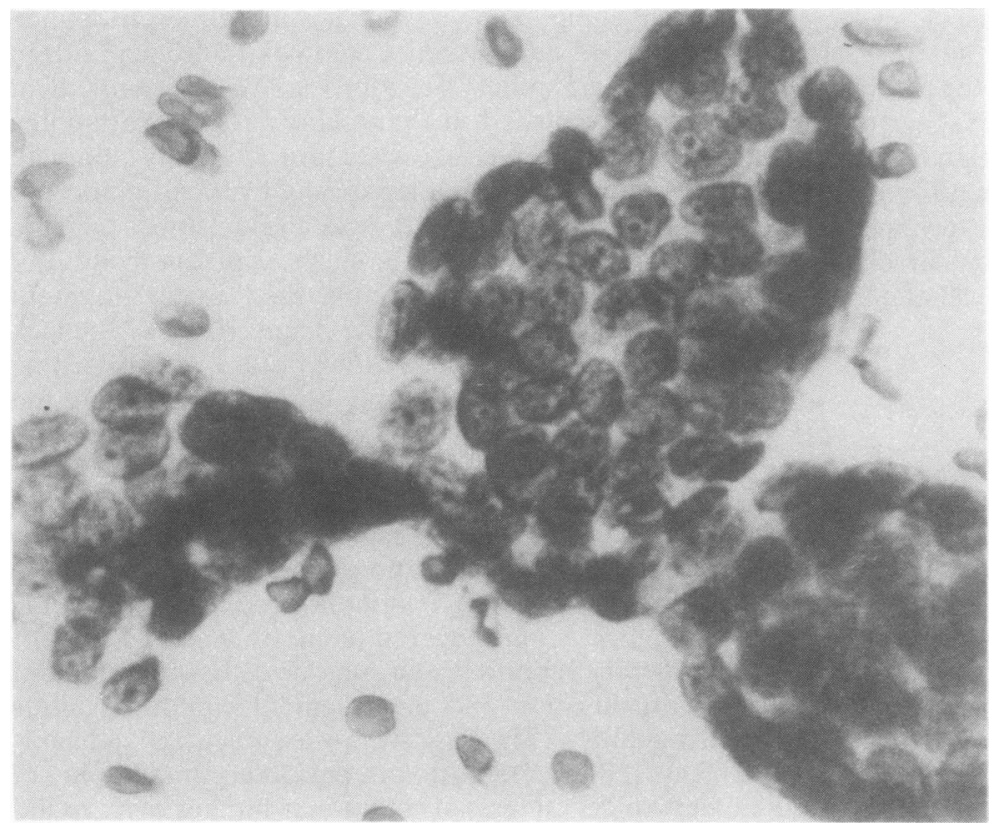

Fig. 3 Small papillary fronds with well-defined, smooth contour. The constituent cells are at different focal planes, resulting in a stereoscopic configuration. Haematoxylin and eosin $\times 520$. 


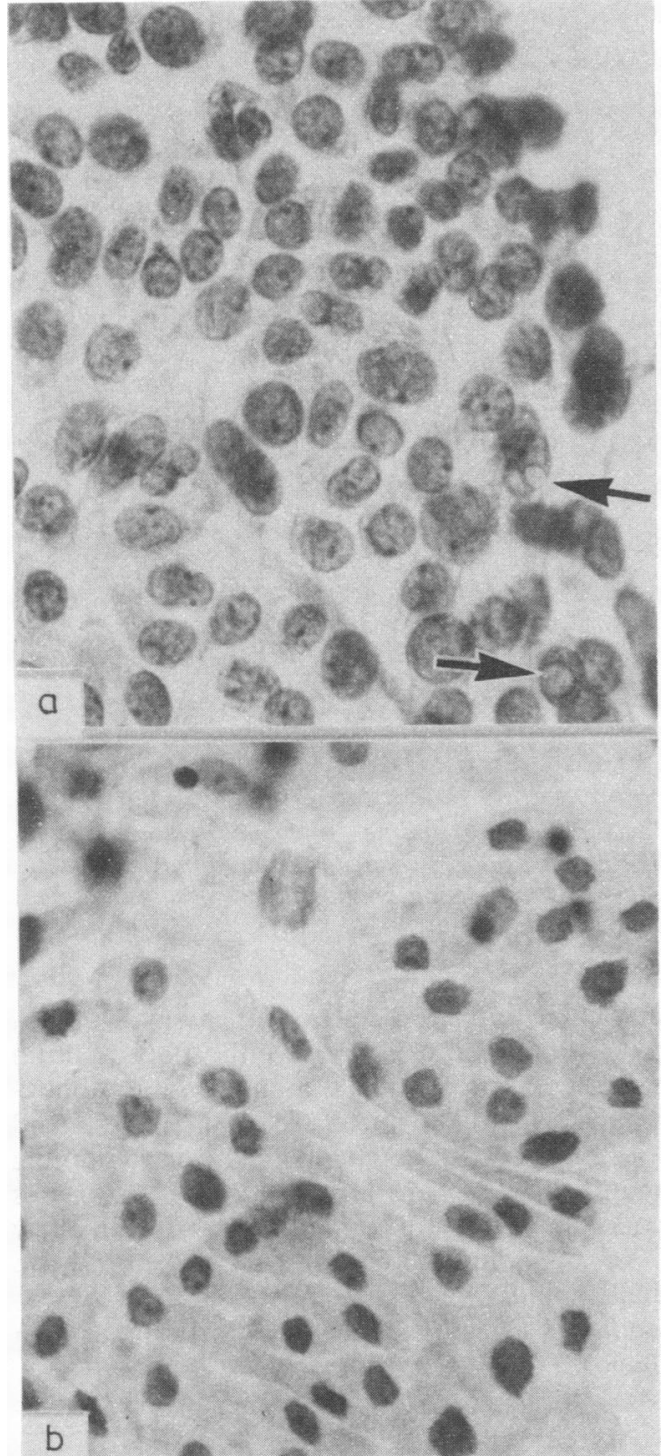

Fig. 4 Monolayered tissue fragments. (a) Note variation in cell size ground glass vesicularity of many nuclei and intranuclear cytoplasmic inclusions (arrows). (b) Note squamoid appearance of tumour cells. Haematoxylin and eosin $(a) \times 520,(b) \times 520$.

on the degree of differentiation. Some investigators $^{1011}$ have attempted to characterise the cytological alterations of cells of follicular carcinoma. These have included nuclear pleomorphism and overlapping, granular chromatinic pattern, conspicuous nucleoli and nuclear size larger than that of adenoma (Fig. 6). Although these parameters may have discriminatory value on a statistical basis, they

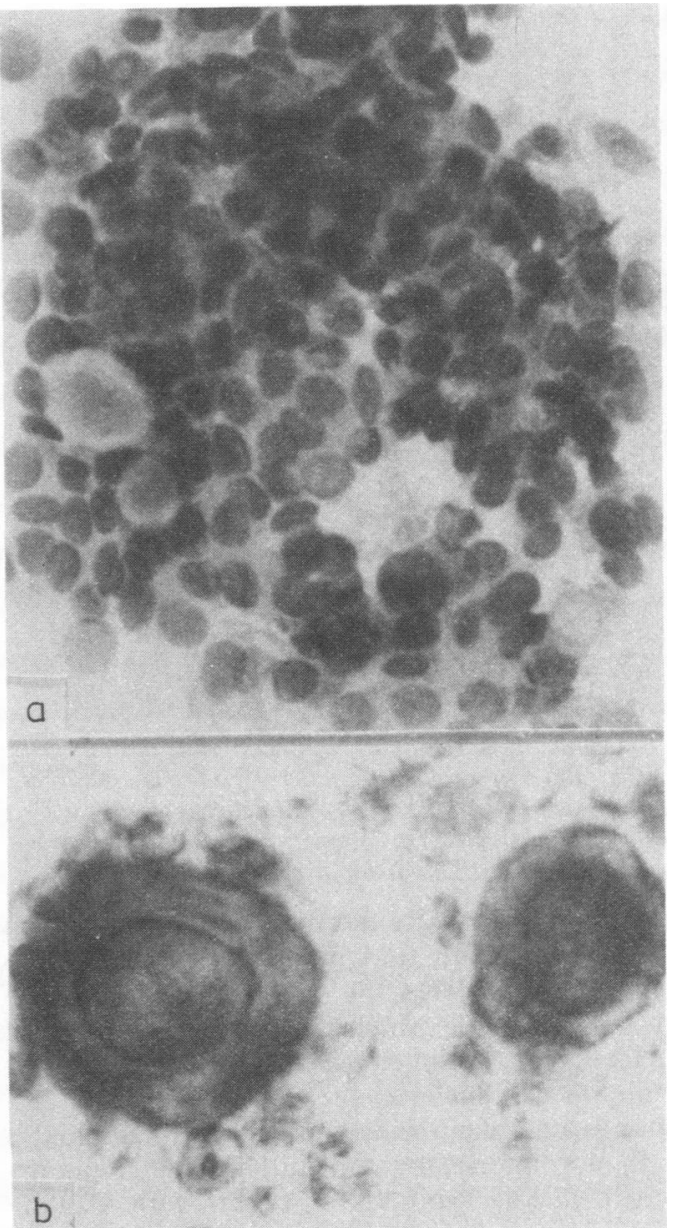

Fig. 5 (a) A group of tightly packed, superimposed tumour cells forming a multilayered tissue fragment. (b) Two psammoma bodies. Haematoxylin and eosin (a) $\times$ 400 , (b) $\times 520$.

are not absolute and we have found them less useful when applied to individual cases of welldifferentiated follicular carcinoma whose nuclear features frequently overlap those of adenoma. Most authors ${ }^{1213}$ agree that the final diagnosis should rest on careful histological examination which permits evaluation of the entire capsule and inspection for vascular involvement.

\section{Medullary carcinoma (Fig. 7)}

As with all malignant tumours, the aspirates are cellular. The tumour cells are arranged singly and in loosely cohesive groups. The predominant cells are the small, polyhedral cells with little pleomorphism. The nuclei are round to oval with hyperchromatic, 


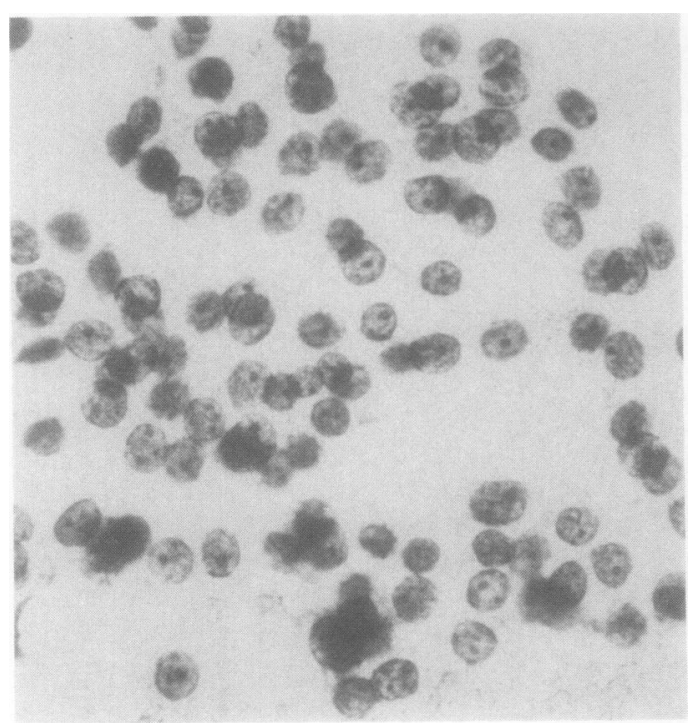

Fig. 6 Follicular carcinoma. Note numerous tumour cells loosely grouped in a follicular pattern. The cells are larger than those from adenoma and each nucleus contains $a$ conspicuous nucleolus. This patient subsequently developed a metastasis in the skull. Haematoxylin and eosin $\times 400$.

chromatin. Nucleoli are not evident. The cytoplasm is usually abundant and many cells contain fine cytoplasmic granules. Other cell forms can often be seen in the same smear: spindle-shaped cells, binucleate and multinucleate cells. Not infrequently, the tumour cell nuclei are eccentrically placed, giving rise to a plasmacytoid appearance. No amyloid is seen in our material, but amyloid has been demonstrated in needle aspirates by others with alkaline Congo red stain. ${ }^{14}$ Even in the absence of amyloid, the combination of different cell forms with predominance of the small polyhedral cells, intracytoplasmic granulation and plasmacytoid appearance of some tumour cells are cytologically suggestive of medullary carcinoma.

\section{Follicular adenoma (Fig. 8a \& 8b)}

The aspirates contain many tumour cells occurring in discrete small accinous units or in larger cell sheets with a follicular pattern. The nuclei are round and regular, usually.smaller than those seen in follicular carcinoma. The chromatin is evenly distributed and the nucleoli are frequently invisible. However, some cell samples obtained from an atypical adenoma or an adenoma with retrogressive changes may reveal cellular atypia that may be confused with carcinoma. $^{15}$

\section{Colloid goitre (Fig. 9)}

These samples are characteristically hypocellular.

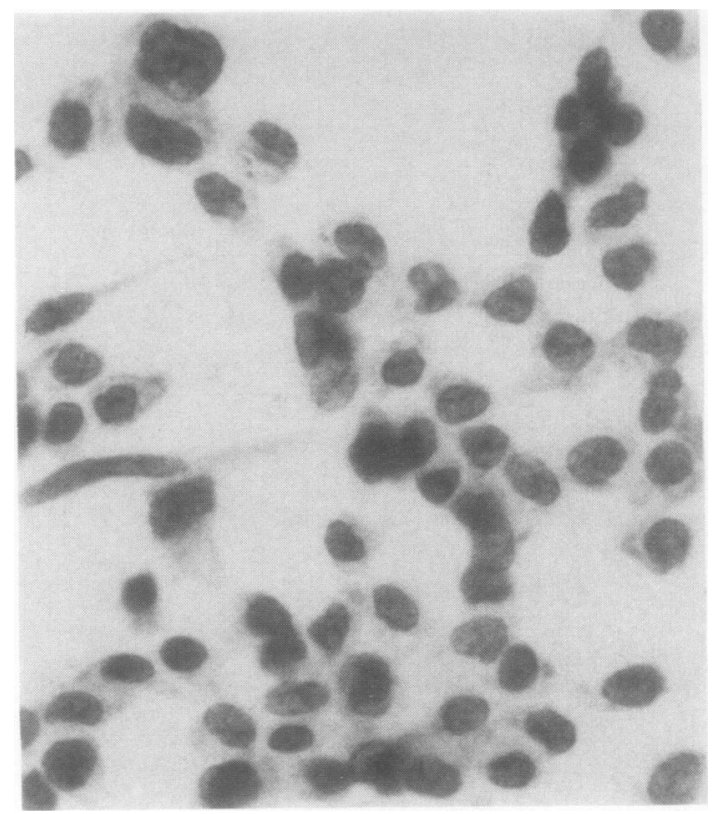

Fig. 7 Medullary carcinoma. Note combination of small polyhedral cells, spindle-shaped cells and binucleate cells. Cytoplasm of many cells is abundant and contains granules. Haematoxylin and eosin $\times 480$.

The follicular epithelial cells occur in small mono? layered sheets. The cells are evenly spaced within the cell sheets, presenting a monomorphic honeycomb appearance. The nuclei are small, uniform and oval to round with homogeneously dark-staining chromatin. Nucleoli are absent. Foamy histiocytes and colloid globules are commonly present. In a few cases of adenomatous goitre, the aspirates are unusually cellular and can be mistaken for a follicular neoplasm. Even histological distinction may be a problem.

\section{Cysts}

Cystic lesions for the most part represent degenerated involutional goitres with a predominant cystic component. The aspirated fluid ranges from clear yellow to dark brown and typically contains a large number of histiocytes, some of which may be laden with haemosiderin pigments. A scant number of $\sigma$ benign-appearing, atrophic follicular epithelial cells $\tilde{O}$ are present.

About $3 \%$ of the cystic lesions in our series proved to be derived from cystic papillary carcinoma. Chu and associates ${ }^{16}$ warn that the $\stackrel{\odot}{\odot}$ pathologist should always routinely consider papil- $\stackrel{\mathscr{D}}{\rightarrow}$ lary carcinoma when examining a cystic lesion even 0 though the vast majority of the cysts are benign. Cell 


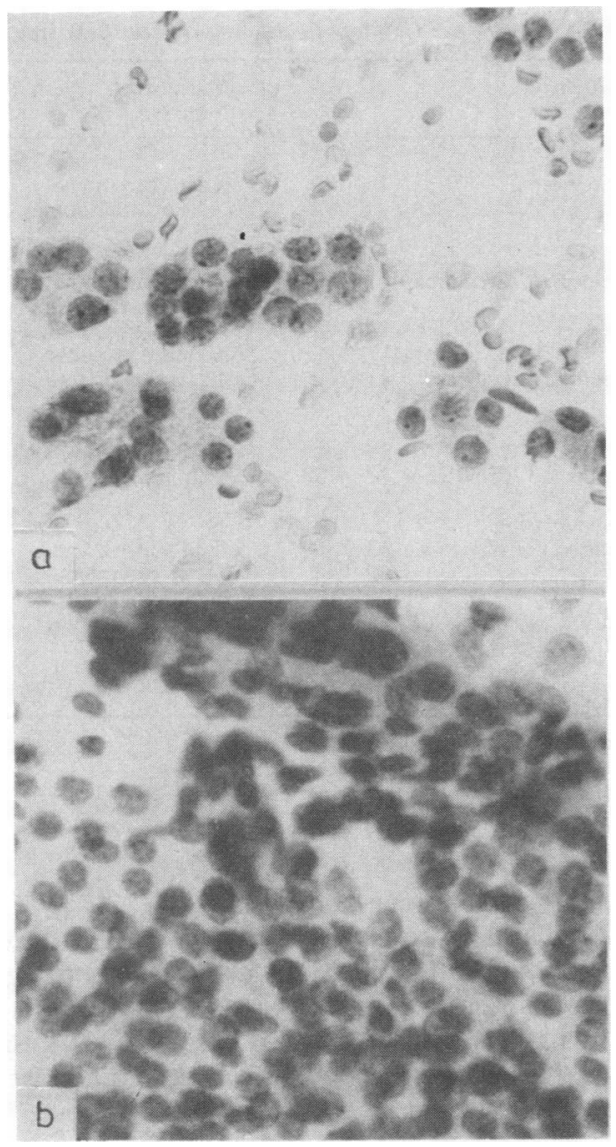

Fig. 8 Follicular adenomas. (a) Uniform tumour cells forming discrete follicular units. (b) A multilayered tissue fragment within which a follicular pattern is discernible. Haematoxylin and eosin $(a) \times 400,(b) \times 400$.

blocks or millipore preparations or both should be made to minimise the risk of missing the cancer cells.

\section{Thyroiditis}

Aspirates of chronic lymphocytic thyroiditis or Hashimoto's thyroiditis show abundant small lymphocytes with variable numbers of plasma cells and histiocytes. When a germinal centre is aspirated, stimulated lymphocytes at various stages of maturation are seen, reminiscent of the cellular content of a hyperactive lymph node. Hürthle cells with pale, oxphilic cytoplasm are frequently present (Fig. 10a). The nuclei of the Hürthle cells sometimes can be quite large and atypical, simulating a Hürthle cell tumour. In thyroiditis, however, an additional population of "normal" Hürthle cells with smaller and regular nuclei is also present, giving rise to a cytolog-

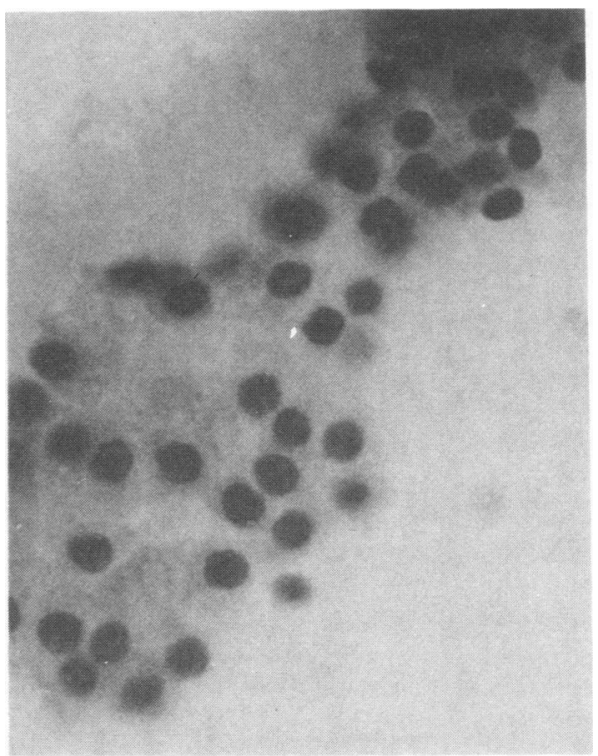

Fig. 9 Colloid goitre. Figure shows a small sheet of uniform, evenly-spaced follicular epithelial cells. Haematoxylin and eosin $\times 520$.

ical pattern referred by Nilsson ${ }^{17}$ as "discontinuous anisokaryosis" (Fig. 10b). Conversely, smears of a Hürthle cell tumour show usually a uniform single population of neoplastic cells.

Other forms of thyroiditis are not specific on aspiration but may be suspected from clinical features correlated with dominant inflammatory cells seen on the smears, including the multinucleate giant-cell form..$^{13}$ On the other hand, Perrson ${ }^{18}$ expresses the opinion that different types of thyroiditis can be distinguished on cytological grounds.

\section{Results}

The Table shows the results of FNAB and the follow-up data of the 304 patients. Seventy-one cases were diagnosed by FNAB as neoplastic or probably neoplastic. Seventy patients underwent surgical exploration and 65 neoplasms were found (34 carcinomas, 1 lymphoma and 30 adenomas). The remaining five cases proved to be nonneoplastic, including four adenoma-like colloid goitres and one subacute thyroiditis. One case reported by cytology as "suspicious for lymphoma" did not undergo operation because the clinical presentation was that of chronic lymphocytic thyroiditis and the swelling subsided after thyroid suppressive therapy. Hence, altogether there were six false positive cytological reports.

Follow-up of the 233 cases diagnosed as non- 


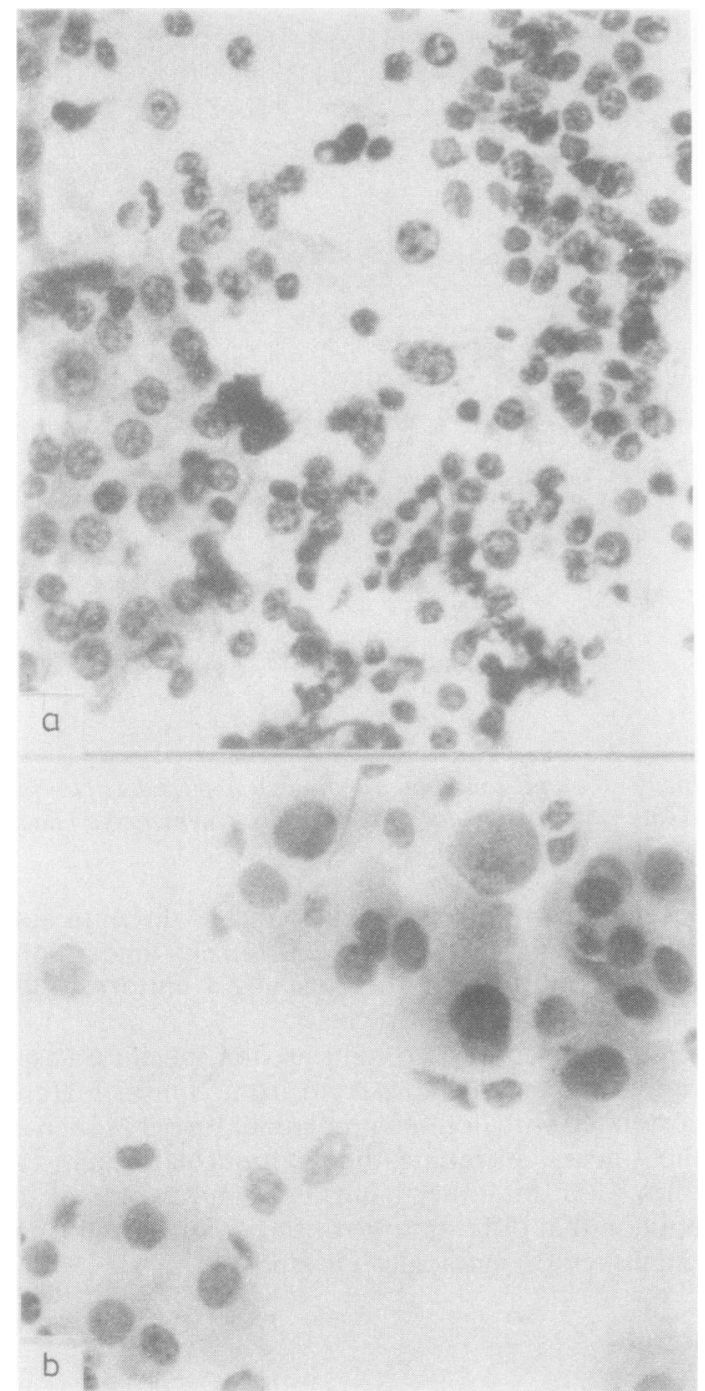

Fig. 10 Hashimoto's thyroiditis. (a) Typical aspirate showing numerous lymphocytes at various stages of maturation. A sheet of Hürthle cells is present on the left. (b) Aspirate showing Hürthle cell hyperplasia. Note admixture of normal-sized Hürthle cells and enlarged atypical Hürthle cells. Haematoxylin and eosin (a) $\times 400,(b) \times 400$.

neoplastic by cytology showed that nine nodules had been treated surgically (Table). The nine cases comprised two papillary carcinomas, three benign cystic goitres, three solid colloid goitres and one chronic lymphocytic thyroiditis. The first two cases represented false-negative cytological reports. The other 224 cytologically benign cases did not show any clinical justification for operation. The benign diagnoses were substantiated by a period of follow-
Table Results of 304 fine needle aspiration biopsies

\begin{tabular}{|c|c|c|c|c|}
\hline $\begin{array}{l}\text { Cytological } \\
\text { diagnosis }\end{array}$ & & $\begin{array}{l}\text { No } \\
\text { surgery }\end{array}$ & $\begin{array}{l}\text { Surgery with } \\
\text { histology }\end{array}$ & \\
\hline \multicolumn{5}{|l|}{ Neoplasms } \\
\hline Carcinoma & 16 & 0 & $\begin{array}{l}\text { Papillary carcinoma } \\
\text { Poorly diff carcinoma } \\
\text { Follicular carcinoma } \\
\text { Medullary carcinoma }\end{array}$ & $\begin{array}{r}12 \\
2 \\
1 \\
1\end{array}$ \\
\hline Suspected carcinoma & 12 & 0 & $\begin{array}{l}\text { Papillary carcinoma } \\
\text { Follicular carcinoma } \\
\text { Medullary carcinonıa } \\
\text { Subacute thyroiditis }\end{array}$ & $\begin{array}{l}7 \\
3 \\
1 \\
1^{*}\end{array}$ \\
\hline Follicular neoplasm & 41 & 0 & $\begin{array}{l}\text { Follicular carcinoma } \\
\text { Papillary carcinoma } \\
\text { Adenoma } \\
\text { Colloid goitre }\end{array}$ & $\begin{array}{c}6 \\
1 \\
30 \\
4^{*}\end{array}$ \\
\hline Suspected lymphoma & 2 & $1^{*}$ & Lymphoma & 1 \\
\hline \multicolumn{5}{|l|}{ Non-neoplasms } \\
\hline $\begin{array}{l}\text { Colloid goitre } \\
\text { Cysts }\end{array}$ & $\begin{array}{r}133 \\
59\end{array}$ & $\begin{array}{r}130 \\
54\end{array}$ & $\begin{array}{l}\text { Colloid goitre } \\
\text { Papillary carcinoma } \\
\text { Benign cystic goitre }\end{array}$ & $\begin{array}{l}3 \\
2 \dagger \\
3\end{array}$ \\
\hline $\begin{array}{l}\text { Chronic lymphocytic } \\
\text { thyroiditis }\end{array}$ & 41 & 40 & $\begin{array}{l}\text { Chronic lymphocytic } \\
\text { thyroiditis }\end{array}$ & 1 \\
\hline Total & 304 & 225 & & 79 \\
\hline
\end{tabular}

*False-positive (6 cases).

+False-negative ( 2 cases)

No of neoplasms $=67$.

No of malignancies $=37$.

up ranging from one to five years.

In the entire series of 304 patients, 79 underwe $\vec{\varphi}$ operation. The incidence of neoplasms among the surgically excised nodules was $85 \%$ (67 of 79) an the incidence of malignancy 47\% (37 of 79). Sixt five of the 67 thyroid neoplasms were diagnosed or suspected on fine needle aspiration biopsy. Two cases were missed. The sensitivity of the aspiration $\mathbb{Q}$ biopsy (percentage of neoplasms detected by the $\overrightarrow{\vec{A}}$ test) and the positive predictive value of the test $\frac{3}{3}$ (percentage of correct positive diagnoses) were calculated according to Galen and Gambino's method $^{19}$ as follows:

$$
\begin{aligned}
\text { Sensitivity } & =\frac{\text { true positives }}{\text { true positives }+ \text { false negatives }} \times 100 \\
& =\frac{65}{65+2} \times 100=97 \%
\end{aligned}
$$

Positive predictive value $=$

$$
\begin{gathered}
\frac{\text { true positives }}{\text { true positives }+ \text { false positives }} \times 100 \frac{\text { 票 }}{\frac{N}{N}} \\
=\frac{65}{65+6} \times 100=91 \%
\end{gathered}
$$

The given number of false-negative cases (2) is a low estimate, because most of the cytologically "benign" cases were not treated surgically and the period of ${ }_{\bar{D}}$ clinical follow-up was short (one to five years). Also, $\stackrel{5}{?}$ we deleted the 15 cases of technical failure from 0 consideration in our results. Of these 15 cases, 
follow-up showed two Hürthle cell adenomas and if these two were included as false-negatives in the calculation of "sensitivity", the result would be slightly lower-that is, $94 \%$.

\section{Discussion}

FNAB is essentially a cytological method and for diagnosis requires a much smaller sample than that needed for histological examination. Many physicians who are not aware of the differences between FNAB and the histological biopsy obtained by a thick-core needle (Tru-Cut or Vim-Silverman needle) have unjustifiably regarded FNAB as an easy and less accurate modification of the histological biopsy. It is important to note that the accuracy of cytological diagnosis, as far as thyroid aspiration is concerned, compares favourably with that of the thick-core biopsy. ${ }^{20}{ }^{21}$ Among the many reports that consider the accuracy of FNAB, results vary, but in most large series the overall accuracy rate exceeds $90 \%$ with a 5 to $10 \%$ frequency of false-positives and false-negatives. ${ }^{12} 1622-24$ There are other advantages of fine needle aspiration biopsy. It is a simple and safe procedure that can be performed on outpatients, with wide patient acceptance. It is cost effective, and can be repeated as necessary. Local anaesthesia, needed for thick-core biopsy, is not necessary. Complications such as haematoma formation and transitory vocal cord paralysis encountered rarely with the Vim-Silverman or Tru-Cut biopsy, are even rarer with the fine needle biopsy. ${ }^{22-25}$ Two cases of tumour implantation in the needle tract following the use of Vim-Silverman needle have been recorded in the literature. ${ }^{20} 26$ Recently, Block et $a^{27}$ reported a subcutaneous implant of thyroid carcinoma six months after surgical excision of the tumour in a patient whose preoperative assessment included fine needle biopsy. The authors were careful to point out that it was difficult to be certain of the origin of the tumour implant. The large scale use of fine needle aspiration in Scandinavia has yet to result in any reports of cancer implantation in the needle tract. ${ }^{12}$ is While the rarity of complications and the many advantages associated with FNAB have encouraged more physicians to use the FNAB technique in preference to the thick-core biopsy, others still feel that the technique has very little value as a routine procedure in the investigation of thyroid nodules. ${ }^{32} 29$ Opponents to the FNAB technique insist that accurate diagnosis of a thyroid nodule can only be ascertained by complete excision of the lesion.

It has been pointed out that the value of a procedure must be judged on more than merely correct diagnosis: the final arbiter is how a technique influences clinical practice. ${ }^{30}$ To assess the impact of FNAB on patient care, we reviewed the pathological reports of all thyroidectomies performed between 1974 and 1977, the four-year period immediately preceding the use of FNAB. Two hundred and forty-seven patients underwent thyroidectomy during that period and 34 patients $(14 \%)$ were found to have malignant lesions. In the aspiration series, 37 patients or $47 \%$ of the 79 patients who underwent surgery had malignancies. Two hundred and sixtyeight operations will be required to salvage the same number of malignancies if FNAB is not used.

All patients undergoing aspiration biopsy in our series were not operated upon and the possibility of missing a malignant tumour is not certain. It may be that the given number of false-negative cases (2) in the series is a low estimate. The literature indicates that the expected incidence of malignancy among "cold" thyroid nodules is between $10 \%$ and $20 \%$. In the present study, a total of 37 cancers was detected, which represents a figure of $16 \%$ malignancy in the total number of "cold" nodules (235). This suggests that the number of thyroid malignancies that we may have missed must have been small or negligible. Identification of all cancers is possible only if every nodule is excised. This is obviously impractical and patient selection is desirable. A low ratio of malignant to benign nodules in a surgical series implies many unnecessary operations. With judicious patient selection, much unnecessary surgery would be saved and most, if not all, cancers would be excised.

It would be unrealistic to assume that cytological diagnosis of thyroid nodules is simple and infallible. Although cancer cells of the thyroid are abnormal, they often lack fully-developed, malignant cytological features. Conceivably, a less-thancertain cytological diagnosis of "suspicious for carcinoma or neoplasm" is not infrequently made on lesions that subsequently prove to be carcinoma on histological examination. This does not lessen the value of cytology as a screening tool because a "suspicious" diagnosis is a clear indication of the need for further investigation or surgical exploration.

False-negative reports can occur in the following circumstances:

(i) In cystic papillary carcinoma. The two falsenegatives in our series belong in this category. On review of the aspirates we still could not detect any cancer cells. This could be explained by the scant number of tumour cells present whose concentration was further diluted by the cystic content. Both lesions were large cystic masses, measuring $4.5 \mathrm{~cm}$ and $5 \mathrm{~cm}$ each, and they promptly recurred following evacuation of the fluid. Walfish $e t a^{31}$ pointed out that although the incidence of malignancy in 
small cystic lesions was generally minimal, cystic degeneration of large malignant lesions could occur. Cysts larger than $4 \mathrm{~cm}$ or prompt reaccumulation of haemorrhagic fluid after repeated aspirations should raise the suspicion of malignancy.

(ii) In the presence of chronic thyroiditis. Chronic lymphocytic thyroiditis can coexist with many types of thyroid cancer. Friedman ${ }^{32}$ stressed that an increased ratio of epithelial to lymphoid cells should arouse suspicion of an epithelial tumour associated with chronic thyroiditis. Hürthle cells of Hashimoto's thyroiditis have to be distinguished from cells derived from a Hürthle cell tumour. Small cell carcinoma or lymphoma can also mimic chronic lymphocytic thyroiditis. ${ }^{32}{ }^{33}$ If the diagnosis of thyroiditis is not supported by the patient's clinical course, further investigation is needed in an attempt to elucidate the cause of the nodule.

(iii) As a result of well-differentiated follicular carcinoma mistaken for adenoma. Since the distinction between the two conditions requires histological demonstration of capsular or vascular invasion, it is our policy to recommend surgical excision of all follicular neoplasms, benign or malignant. This approach is justified not only because it may not be feasible to separate an adenoma from a low-grade carcinoma on cytological evaluation, but also there is some evidence to suggest that occasional adenomas can evolve into carcinomas. ${ }^{34-36}$

(iv) As a result of the needle missing the lesion or an inadequate cell sample. In Varhaug's series $^{24}$ as much as $16 \%$ of their samples were unsatisfactory. In Walfish's series ${ }^{31}$ the unsatisfactory rate was $8 \%$ and in Frable's series ${ }^{13}$ the rate was $7.5 \%$. Aspegren $^{37}$ reported that aspiration cytology was found to be $25 \%$ less accurate when various surgeons performed the aspiration than when it was performed by trained cytopathologists. Inadequate aspiration, failure in making acceptable smears, or faulty fixation were reasons for this difference. In our material the unsatisfactory biopsies constituted $5 \%$ of the total. The same three physicians (two endocrinologists and one radiologist) performed $90 \%$ of the biopsies. For each case, an average of two aspirations were performed, and if the biopsy was judged inadequate by gross inspection of the smears it was repeated immediately.

The most common causes of false positive cytological reports in our study were:

(i) Cellular colloid goitre mistaken for neoplasm. Four such cases of cellular colloid nodule were surgically treated because they were diagnosed as neoplastic on FNAB.

(ii) Thyroiditis mistaken for neoplasm. One case of chronic lymphocytic thyroiditis was cytologically labelled as lymphoma and one case of subacute thyroiditis diagnosed as "suspected carcinoma" (Table).

In conclusion, we wish to stress that the true value of fine needle aspiration biopsy lies in patient selection and case identification. In order to maintain a high sensitivity ( $97 \%$ in our study) for cancer detection we overdiagnosed some non-neoplasms as neoplastic, sacrificing somewhat the predictive value of the positive reports $(91 \%)$. We believe that a few false-positive reports are acceptable if one does not is wish to miss any of the malignant nodules. Further- $\vec{\circ}$ more, many more of the benign "cold" nodules would be operated on if FNAB is not in use. FNAB is not a final diagnostic work-up and a conclusive cytological diagnosis is not always required, but each result, if suspicious for neoplasm, should lead to $\omega$ further investigations that will identify a specific 6 lesion and in most instances this would mean surgical exploration.

\section{References}

${ }^{1}$ Degroot LJ. Most solitary thyroid nodules should be removed. $\mathbb{D}$ In: Ingelfinger FJ, ed. Controversy in internal medicine II. Philadelphia: WB Saunders Co, 1974:421-7.

${ }^{2}$ Geer MA. Thyroid nodules. Surgery is usually not necessary. In: Ingelfinger FJ, ed. Controversy in internal medicine II. \} Philadelphia: WB Saunders Co, 1974:428-36. ${ }^{3}$ Beckers C. Thyroid nodules. Clin Endocrinol Metol $\overrightarrow{0}$

4 Sokal JE. The problem of malignancy in nodular goitre. JAMA 1959;170:405-12.

${ }^{5}$ Kendall LW, Condon RE. Prediction of malignancy in solita thyroid nodules. Lancet 1969;i:1071-3.

'Knowlson GTG. The solitary thyroid nodule. Br J Surg 1971;58:253-4.

"Katz AD, Zager WJ. The malignant "cold" nodule of the thyroid. Am J Surg 1976;132:459-62.

${ }^{8}$ Sobel HJ. Cytoplasmic invaginations resembling nuclear inclusions. Arch Pathol 1968;85:114-5.

${ }^{9}$ Burns ER, Soloff BL, Hanna C, Buxton DF. Nuclear pockets associated with the nucleolus in normal and neoplastic cells. Cancer Res 1971;31:159-61.

${ }^{10}$ Lang W, Atay Z, Georgii A. The cytological classification of follicular tumours in the thyroid gland. Virchows Arch (Pathol Anat) 1978;378:199-211.

${ }^{11}$ Boon ME, Löwhagen T, Willems JS. Planimetric studies on fine needle aspirates from follicular adenoma and follicular carcinoma of the thyroid. Acta Cytol 1980;24:145-8.

${ }^{12}$ Löwhagen T, Granberg P, Lundell G, Skinnari P, Sundblad R. $\mathrm{O}$ Willems JS. Aspiration biopsy cytology (ABC) in nodules of the thyroid gland suspected to be malignant. Surg Clin North Am 1979;59:3-18.

${ }^{13}$ Frable WJ, Frable MA. Fine needle aspiration biopsy of the thyroid. In: Fenoglio CM, Wolffe M, ed. Progress in surgical o pathology Vol 1. New York: Masson, 1980:105-18.

${ }^{14}$ Ljungberg $O$. Cytological diagnosis of medullary carcinoma of the thyroid gland. With special regard to the demonstration of $\omega$ amyloid in smears of fine needle aspirates. Acta Cytol 1972;16:253-5.

is Zajicek J. Aspiration biopsy cytology, Part 1. Cytology of $\mathscr{C}$ supradiaphragmatic organs. New York: S Karger, 1974.

${ }^{16} \mathrm{Chu}$ EW, Hanson TA, Goldman JM, Robbins J. Study of cells in fine needle aspirations of the thyroid gland. Acta Cytol $\square$ 1979;23:309-14. 
${ }^{17}$ Nilsson G. Nuclear size classes in the follicular epithelium of lymphoid thyroiditis. Acta Pathol Microbiol Scand[A] 1976;84:165-71.

18 Persson PS. Cytodiagnosis of thyroiditis. Acta Med Scand (Suppl) 1968;483:8-100.

${ }^{19}$ Galen RS, Gambino SR. Beyond normality. The predictive value and efficiency of medical diagnosis. New York: John Wiley \& Sons, 1975.

${ }^{20}$ Wang C, Vickery AL, Maloof F. Needle biopsy of the thyroid. Surg Gynecol Obstet 1976;143:365-8.

${ }^{21}$ Esselstyn CB Jr, Crile G Jr. Needle aspiration and needle biopsy of the thyroid. World J Surg 1978;2:321-9.

${ }^{22}$ Einhorn J, Franzen S. Thin needle biopsy in the diagnosis of thyroid disease. Acta Radiol 1962;58:321-36.

${ }^{23}$ Frable MA. Frable WJ. Thin needle aspiration biopsy of the thyroid gland. Laryngoscope 1980;90:1619-25.

${ }^{24}$ Varhaug JE, Segadal E, Heimann P. The utility of fine needle aspiration biopsy cytology in the management of thyroid tumors. World J Surg 1981;5:573-7.

${ }^{25}$ Friedman M, Shimaoka K, Getaz P. Needle aspiration of 310 thyroid lesions. Acta Cytol 1979;23:194-204.

${ }^{26}$ Crile G Jr. Management of thyroid disease with particular reference to thyroid nodules. Postgrad Med J 1976;60:105-8.

${ }^{27}$ Block MA, Miller JM, Kini SR. The potential impact of needle biopsy on surgery for thyroid nodules. World J Surg $1980 ; 4: 737-45$.

${ }^{28}$ Rosai J. Ackerman's surgical pathology Vol 1. St Louis: CV Mosby, 1981:370-1.

${ }^{29}$ Dent DM, Miller A, Louw JH. The place of surgery in nodukir thyroid disease. $S$ Afr Med J 1975;49:354-7.

${ }^{30}$ Anonymous. Utility of needle aspiration of tumours. $\mathrm{Br}$ Med $\mathrm{J}$ 1978;i:1507-8.

${ }^{31}$ Walfish PG, Hazani E, Strawbridge HTG, Miskin M, Rosen IB. Combined ultrasound and needle aspiration cytology in the assessment and management of hypofunctioning thyroid nodule. Ann Intern Med 1977;87:270-4.

${ }^{32}$ Friedman M, Shimaoka K, Rao U, Tsukada Y, Gavigan M, Tamura K. Diagnosis of chronic lymphocytic thyroiditis (nodular presentation) by needle aspiration. Acta Cytol 1981;25:513-22.

${ }^{33}$ Kini SR, Miller JM, Hamburger JI. Problems in the cytologic diagnosis of the "cold" thyroid nodule in patients with lymphocytic thyroiditis. Acta Cytol 1981;25:506-12.

${ }^{34}$ Lahey FH, Hare HH. Malignancy in adenomas of the thyroid. JAMA 1951;145:689-95.

${ }^{35}$ Silverberg SG, Vidone RA. Adenoma and carcinoma of the thyroid. Cancer 1966;19:1053-62.

${ }^{36}$ Meissner WA, Warren S. Tumors of the thyroid gland. Atlas of tumor pathology 2nd series. Washington DC: Armed Forces Institute of Pathology, 1969:61-2.

${ }^{37}$ Aspegren K, Biörklund A, Söderström N, et al. Fine needle aspiration biopsy in thyroid carcinoma. Läkartidningen 1976;73:730-2.

Requests for reprints to: Dr KC Suen, Department of Pathology, Vancouver General Hospital, 855 W 12th Avenue, Vancouver, BC, Canada V5Z 1M9. 